\title{
Librarians' Attitudes Toward Networking
}

\section{Peggy Chapman}

Abstract. Networking, as an answer to library problems, is a concept that is receiving much attention. The attitudes toward networking of public librarians and school media specialists in Winston-Salem, North Carolina, were surveyed. While both groups agreed that there are many benefits to be derived from networking, more public librarians than media specialists expressed a willingness to participate in inter-library cooperation. Lack of clerical help was the overwhelming barrier identified by the media specialists.

In the world today, the information explosion is requiring immediate access to an abundance of resources; at the same time, libraries are facing uncertain funding. Some manner of cooperative effort seems to be inevitable if libraries are to bring their services efficiently and economically to those who need and want them. These cooperative efforts might require some major changes in the rules, regulations, and responsibilities that libraries have traditionally observed.

\section{Networking}

The system of obtaining resources from other agencies is called networking. In many circles of librarianship, this cooperation, or networking, is meeting with some resistance. If it is true that networking is effective at mobilizing total library resources, why is there opposition? The answers seem to lie in the attitudes librarians have toward networking. The question most frequently asked is whether such different kinds of libraries can truly share ideas, services and resources. One concern is that federal funding will not be continued and that networking will be resisted as librarians become more concerned about restricting the use of their collections to their patrons only. One problem in undertaking networking is getting people to work together productively.

If librarians' attitudes prevent them from wholeheartedly supporting the network concept, then this solution to the problems of increased

\footnotetext{
Peggy Chapman is Acting Coordinator of Media Services for the Winston-Salem/Forsyth County Schools.
}

library costs, increased demands for information, and greater cuts in library budgets will have little chance for success.

\section{Networking in Schools and Public Libraries}

Although there is a wealth of material in the literature on networks (e.g., the benefits of, barriers to, and history of the movement), there is very little descriptive research on how the attitudes of librarians affect their use of networks.

Illinois has been a leader among the states involved in networking. As early as 1965 the Library Systems Act was passed, providing for the establishment and development of a network of library systems. Much progress has been made in implementing this law. However, Robert Drescher, in an article written for Illinois Libraries in 1976, listed some barriers that still existed. Prominent among these barriers were several that directly relate to librarians' attitudes. ${ }^{1}$

Networking seems to work best when used among people who associate with each other in professional activities and who are friendly with each other. ${ }^{2}$ For cooperation to work, attitudes must be favorable, not only at the administrative level but also at the points of contact at all levels of activity.

In 1977 Johnson and Hines ${ }^{3}$ prepared a position paper for the Task Force on the Role of the School Library Program in Networking. In this paper, the authors stated that the literature showed the attitudes of librarians and some library users to be the major obstacle to participation in networks.

One bright note in the sometimes gloomy picture of uncooperative attitudes is found in a report by David W. Griffith. He enthusiastically enumerated all the forms of cooperation in which his library in Youngstown, Ohio, was involved for one year. He also emphasized the importance of attitude. ${ }^{4}$

Librarians raise many objections to networking when faced with the question of interlibrary cooperation. Many school librarians feel that they have little to contribute to a system of networking. Some personnel in larger libraries feel that, in 
joining a network, they will be overrun with requests and that their collections will be depleted. Although some of these fears are legitimate, there is reason to agree that "some observe that obstacles to resource sharing are not primarily technological but are human in nature. ${ }^{.5}$

\section{Hypothesis}

$\mathrm{H}_{\mathrm{O}}$ : There will be no significant difference in the attitudes of public librarians and of school media specialists toward networking.

\section{Methodology}

In order to assess whether the attitudes toward networking of public librarians are different from the attitudes of school librarians, a survey was conducted. The questionnaire was designed to ensure the anonymity of the librarian responding to the questions. In the upper right corner were the initials PL (for public librarian) or SL (for school librarian). These initials were necessary to identify the type of library from which the questionnaire was returned. There was no other mark of identification. A cover letter explaining the need for their opinions was sent with the questionnaire to the sixty-eight media specialists in the Winston-Salem/Forsyth County (North Carolina) schools and to the thirty-three professional librarians in the Forsyth County Public Library system. A stamped addressed envelope was enclosed.

Of the sixty-eight questionnaires sent to school media specialists, forty-eight were completed and returned. Table I illustrates the number of elementary, middle schools, junior high schools, and high schools represented by the completed questionnaires. The number of media specialists and the number of aides working in these media centers are also shown on the chart. It is evident that in most of the schools, the media center has a staff of only one person.

\begin{tabular}{|c|c|c|c|}
\hline \multicolumn{4}{|c|}{$\begin{array}{c}\text { TABLE I } \\
\text { Media Centers }\end{array}$} \\
\hline Level & Number & Media Specialists & Aides \\
\hline Elementary & 23 & 24 & 3.5 \\
\hline Middle School & 4 & 4 & 0 \\
\hline Junior High & 7 & 7 & 0 \\
\hline High School & 14 & 22 & 9.0 \\
\hline
\end{tabular}

Most of the schools in the Winston-Salem Forsyth County System have a large number of elementary and middle schools with each school serving relatively few patrons. The junior high and high schools are fewer in number, but each serves a greater number of students. (See Table II.)
TABLE II

Users Served

\begin{tabular}{lccc}
\hline Level & $300-599$ & $600-1000$ & Over 1000 \\
\hline Elementary & 14 & 7 & 2 \\
Middle School & 3 & 1 & 0 \\
Junior High & 4 & 3 & 0 \\
High School & 0 & 5 & 9 \\
\hline
\end{tabular}

It is apparent (Table III) that even in the smaller elementary schools the collections in each school are fairly substantial.

Of the thirty-three questionnaires sent to the professional librarians in the Forsyth County Public Library, twenty were completed and returned. Table IV illustrates the way in which the librarians, aides, users served, and collections are divided between the main library and the branch libraries.

\section{Summary of Survey Data}

Each librarian and media specialist was asked to put a check by selected types of materials on hand in his/her library. The questionnaire also instructed the librarians and media specialists to check the types of materials that they have requests or needs for and the types that they would be willing to lend to other facilities. The tabulations indicate that all the libraries and media centers contain most of these materials. Seventy-one per cent of the school libraries, but only 45 per cent of the public libraries have filmstrips; 73 per cent of school and 75 per cent of public libraries have records. All of the libraries contain fiction and non-fiction books. Seventyone per cent of the school and 60 per cent of the public libraries have AV equipment; 67 per cent of the school and 90 per cent of the public libraries have documents or pamphlets.

We asked to indicate how long a loan period they would consider satisfactory for sharing materials with other facilities, the public librarians were willing to use a longer time period. (See Table V.)

The librarians and media specialists were asked to list the benefits and drawbacks that they perceived as important in implementing interlibrary loans. The media specialists listed as benefits:

1. that materials not owned by individual media centers would become available to them (79 per cent),

2. that there could be a cost saving if there were less duplication in acquisitions (19 per cent),

3. that there would be an advantage in being able to work with other media specialists (4 per 
TABLE III

Collection Sizes - Books \& AV

\begin{tabular}{lcc} 
& More Than 7500 Items \\
\hline Level & Fewer Than 7500 Items & 21 \\
\hline Elementary & 2 & 3 \\
Middle School & 1 & 6 \\
Junior High & 1 & 13 \\
High School & 1 & \\
\hline
\end{tabular}

TABLE IV

Public Library

\begin{tabular}{lccccc}
\hline & & Fewer Thàn & Over & 7500 Items & 7500 Items \\
Librarians & Aides & 300 & 1000 & Or More & Or More \\
& & Users & Users & Books Only & Books \& AV \\
\hline
\end{tabular}

\begin{tabular}{|c|c|c|c|c|c|c|}
\hline Main Library & $\begin{array}{l}25 \\
10\end{array}$ & $\begin{array}{l}33.5 \\
20\end{array}$ & $\begin{array}{l}0 \\
1\end{array}$ & $\begin{array}{l}1 \\
5\end{array}$ & $\begin{array}{l}0 \\
2\end{array}$ & $\begin{array}{l}1 \\
4\end{array}$ \\
\hline
\end{tabular}

cent),

4. that interlibrary loans would be convenient for students (4 per cent),

5. that they believed the maximum use of materials would be a benefit of networking ( 4 per cent).

The public librarians considered the following items to be benefits of cooperation:

1. that more books would be available to their patrons ( 75 per cent),

2 . that there would be a cost saving in acquisitions with less duplication (40 per cent),

3 . that they would have more satisfied patrons (25 per cent),

4. that networking is a way to secure more current and varied materials (20 per cent),

5 . that interlibrary loans would make available to them out-of-print children's books (10 per cent).

There was general agreement between the two types of librarians that more materials would be available to them and to their patrons through networking. The public librarians foresaw the possibility of a much greater cost savings in acquisitions than the media specialists did.

Media specialists saw as drawbacks to networking:

1. lack of clerical help, thereby involving too much of their time and effort ( 75 per cent),

2. that their users would be deprived of materials (49 per cent),

3. that there would be greater damage to their materials, thereby causing them to have a shorter use time ( 25 per cent),

4. that they would have trouble getting materials on loan returned when they were due (19 per cent),

5. that many of their materials would be lost (17 per cent),

6. that a union catalog could not be kept current enough to be of use to them ( 6 per cent),

7. that they do not have enough materials to lend ( 4 per cent),

8. that the cost of networking would be prohibitive (4 per cent),

9. problems with the transportation of materials (4 per cent),

Drawbacks listed by the public librarians were as follows:

1. that their patrons would be deprived of materials that were on loan ( 35 per cent),

2. that the service would be too slow ( 25 per cent),

3. that cost would be a problem ( 25 per cent),

4. that too much time and effort would be involved in networking (20 per cent),

5. that materials would be kept beyond the due date ( 15 per cent),

6. that there would be "misuse" (not explained) of the network ( 15 per cent),

7. that smaller libraries would benefit more than large libraries (10 per cent),

8. that materials would be lost ( 10 per cent).

Most of the media specialists saw as the major drawback to networking their lack of clerical help. This problem was not a concern of the public librarians. Although both types of librarians felt that their users would be deprived of materials that would be on loan to other facilities,

TABLE V

Loan Periods

\begin{tabular}{lcccc} 
& Week & 2 Weeks & 3 Weeks & 1 Month \\
\hline Public Librarians & 0 & 5 & 2 & 12 \\
School Media Specialists & 7 & 29 & 0 & 5 \\
\hline
\end{tabular}


the media specialists saw this as a bigger problem than the public librarians did. Loss of and damage to materials were concerns to all the librarians, particularly to the media specialists. Ten per cent of the public librarians felt that smaller libraries would benefit more from networking than large libraries. Only one media specialist mentioned this as a problem of library cooperation.

Responses to the question, "Do you feel that you need to know more about networking at your level to perform your job?" differed to a statistically insignificant degree $\left(X^{2}=1.4, \mathrm{df}=1, \mathrm{P}>.05\right)$. of the forty-seven school media specialists answering this question, thirty-two said "yes." Ten public librarians answered in the affirmative, while nine felt that they could engage in networking with the knowledge that they currently possess.

When asked if they felt that having access to materials from other media centers and libraries would outweigh any inconvenience and extra work involved in lending their materials, nineteen out of the twenty public librarians answered that they did. The school media specialists felt different to a significant degree. Of the forty-one media specialists answering this question, only seventeen replied in the affirmative $\left(\chi^{2}=15.94, \mathrm{df}=1\right.$, $\mathrm{P}<.01$ ).

The public librarians and the school media specialists all thought that lending their materials would deprive their users of some services. However, thirty-six out of forty-six media specialists and seventeen out of nineteen public librarians felt that this inconvenience would be relatively small. Although there was a difference, it was not significant. In referring to Tables 3 and 4 , it is apparent that most of the school media centers and the public libraries have substantial collections. Possibly for this reason, both types of librarians felt that they did have enough materials to lend to other facilities. No significant difference between perceptions of media specialists and public librarians occurred on this question $\left(\chi^{2}=\right.$ $3.42, \mathrm{df}=1, \mathrm{P}>.05)$.

When the data were arranged by size of collection (i.e., placing both school and public libraries that own fewer than seventy-five hundred items in one group and libraries owning more than seventy-five hundred items in another group), there was no significant difference in attitudes toward becoming involved in networking.

When questioned about their opinions on the number of loan transactions per month that they would consider satisfactory, the school media specialists overwhelmingly chose the category 0 30 . This choice was the lowest number given in the multiple choice question. The public librarians' answers were evenly divided among the available categories: $0-30 ; 30-50$; and 50 and up $\left(\chi^{2}=51.03, \mathrm{df}=2, \mathrm{P}<.01\right)$.

The consideration of whether the use of networks would add to the cost of operating a library revealed that public librarians and school media specialists differed in their beliefs that costs would increase $\left(\chi^{2}=3.90\right.$, df $\left.=1, P<.05\right)$. This difference was, however, barely significant.

Answers to the last question really summed up the attitudes of all the librarians: it asked if given a choice they would prefer to be involved in networking. Sixteen school media specialists said yes, thirty-two, no; while fifteen public librarians said yes, and four answerd no $\left(\chi^{2}=11.36, \mathrm{df}=1\right.$, $\mathrm{P}<.01)$. This difference is statistically significant and large enough to leave little doubt of the opinions of the librarians surveyed in this study.

\section{Conclusions}

There is a scarcity of literature pertaining to librarians' attitudes toward networking. One study ${ }^{8}$ found that public librarians are not as willing to participate in interlibrary loans as school media specialists. According to another paper, ${ }^{7}$ school librarians were not cooperative either. There seems to be a general consensus that most librarians profess to be interested in networking but would actually prefer not to become involved.

This study was surprising in revealing a great difference between attitudes of school media specialists and public librarians in Winston-Salem and Forsyth County.

The school media specialists believed that the benefits of obtaining materials from other facilities would not be great enough to justify the inconvenience imposed on their own users, who might also be deprived of materials. The opposite view was held by the public librarians. Although they agreed that there would be an inconvenience to users, they felt that the value of library cooperation would outweigh the disadvantages.

In looking for the reasons for the finding that media specialists responded with twice as many negative answers as positive ones, several underlying causes can be found. By referring to Table I, it is evident that many school media centers have practically no staff. In most cases, one person must serve the users indicated in Table II, meet all the classes in the school, serve the needs of the faculty, and process all materials. The WinstonSalem/Forsyth School System does not have central cataloging. Some days, perhaps on the day the questionnaire arrived, one more task might seem to be too much. 
The public librarians serve just as many users as the schools, if not more. Public libraries maintain a larger staff, however, even in branch libraries. Cataloging is done centrally, and books arrive ready to be shelved.

The benefits of networking that the school media specialists and the public librarians listed are strikingly similar. They agree that more and varied materials would be available to their patrons, that costs could probably be cut by reducing duplication in acquisitions, and that their users would be more satisfied with their service.

It is interesting to note that, in enumerating drawbacks to inter-library cooperation, school media specialists listed first their lack of clerical help. The public librarians' first concern was that their users would be deprived of materials while they were on loan. This concern was the second one listed by the school personnel.

There is clear evidence in this survey that, at least in Winston-Salem and Forsyth County, there is a significant difference in the attitudes of public librarians and school media specialists toward networking. The null hypothesis was rejected.

Although the concerns of the school media specialists are justified by their lack of help, a solution to increased costs and lower budgets must be found. Participation in a network will do much to meet student learning needs as well as the resource needs of teachers and the general public. Networks should not be a substitute for effective local media service but should be an expansion of school and public library programs.

According to a plan for library cooperation in Pennsylvania, ${ }^{8}$ collective action works best among people who come in contact with each other in professional organizations and who are friendly with each other. Perhaps opportunities for school media specialists and public librarians to visit each other's libraries would be a good way for them to become acquainted with each other. Actual networking activities could begin on a small scale and grow as the participating libraries become more willing to share their resources.

Workshops or training sessions for the members who would be involved would be useful for working on and solving common problems and fears. At these workshops a handbook of policies, services, and key people could be compiled. In order for communications among libraries to be satisfactory, the time involved in making provisions for sharing materials must be kept to a minimum. By working on policies to deal with problems of this type before networking network- ing is begun, many unsatisfactory situations can be avoided.

The purpose of activities designed to involve different types of librarians in some form of cooperation is, one hopes, to start a change in their attitudes. If attitudes are indeed the major obstacle to networking, a change is needed before any form of networking can be successful. School and public librarians both "face enormous challenges and both will have to change, fundamentally, their attitudes and understandings about each other's programs, about learning and teaching, about services for people, and about information management. ${ }^{n g}$

There is no way to prove conclusively that attitudes direct our choices and our behavior, but there is strong evidence that this is true. Trian$\mathrm{dis}^{10}$ states that attitude is a contributing cause to behavior. "Scientists have felt the need for a concept 'attitude' for this purpose."11 Certainly the connection between attitudes and behavior is a very strong one. The traditional concept has been that the direction of this connection runs from attitude to behavior. There is reason to believe that this connection also runs in the opposite direction, i.e., that behavior sometimes influences the attitude. ${ }^{12}$

\section{References}

1. Robert Drescher, "School Library Cooperation in the Illinois Library and Information Network (ILLINET)," Illinois Librar ies 58 (September 1976): 548-551.

2. C.T. Meadow, A Plan For Library Cooperation in Pennsyl. vania, (Philadelphia: Drexel University, 1976) (ERIC Document Reproduction Service No. ED 136 757).

3. Mary Frances Johnson and Theodore C. Hines, "School Media Programs and Networking: A Position Paper." Greensboro, N.C. University of North Carolina at Greensboro, 1977. (ERIC Document Reproduction Service No. ED 175442 ).

4. David W. Griffith, "Cooperation: What's In a Name?" The Unabashed Librarian \#29 (1978): 32 .

5. David M. Moore, "Library Networks-A Technological System Whose Time Has Come," Journal of Educational Technology Systems 8 (1979-80): 147-53.

6. Esther R. Dyer, "Cooperation in Library Services to Children: A Fifteen Year Forecast of Alternatives Using the Delphi Technique," (Doctoral Dissertation, Columbia University, 1976). Dissertation Abstracts International 39 (1976): 1904A-1905A.

7. Esther B. Woolls, "Cooperative Library Service to Children in Public Libraries and Public School Systems in Selected Communities in Indiana." (Ph.D. Dissertation, Indiana University, 1973). 8. Meadow, op.cit.

9. D. Phillip Baker, "School and Public Library Programs and Information Dissemination," School Media Quarterly 5 (Winter 1977): 120.

10. H.C. Triandis, Attitude and Attitude Change (New York: John Wiley, 1969).

11. C.A. Kiesler, B.E. Collins, and N. Miller, Attitudes Change (New York: John Wiley, 1969): 5.

12. C.A. Insko, Theories of Attitude Change (Englewood Cliffs, N.J.: Prentice-Hall, 1967). 